\title{
PRIVATE EQUITY AND VENTURE CAPITAL IN AN EMERGING ECONOMY: EVIDENCE FROM BRAZIL *
}

\author{
Leonardo de Lima Ribeiro ", FGV Business School and University of São Paulo \\ Antonio Gledson de Carvalho, FGV Business School \\ Cláudio Vilar Furtado, FGV Business School
}

\begin{abstract}
This article, based on the Brazilian experience, examines how Private Equity and Venture Capital $(P E / V C)$ adapts to an emerging economy Our dataset is based on two extensive questionnaires answered by each of the 65 PE/VC organizations with offices in Brazil. The results reveal that a lack of infrastructure and security create investment opportunities. However, institutional idiosyncrasies represent a major barrier and force PE/VC - a U.S. investment model - to adapt by investing in different stages of business development, avoiding LBOs, taking a generalist industry approach, geographically concentrating in the financial cluster and relying on arbitration for dispute resolution.
\end{abstract}

\section{1 - INTRODUCTION}

The outstanding success attained by Private Equity and Venture Capital (PE/VC) in fostering the U.S. entrepreneurial sector has encouraged several countries to develop their own PE/VC industry. However, $\mathrm{PE} / \mathrm{VC}$ was tailored to perform in the American institutional environment. As Gompers and Lerner (2002) state, the degree to which the U.S. venture model will - or can - be successfully adapted to other countries is a particularly interesting question.

To answer this question we collected data from all the $65 \mathrm{PE} / \mathrm{VC}$ organizations with offices in Brazil. The study was conducted at the end of 2004 and attained a response rate of $100 \%$. For this reason, the results are fully representative. The conclusion of the first cycle of PE/VC with a handful of successful IPOs presents a good opportunity to identify adaptations made by the practitioners to the Brazilian idiosyncratic environment. The analysis focuses on the industry's size and structure as related to economic and institutional factors and compares with international evidence. For structural comparison, we refer mostly to Sahlman's (1990) and Bottazzi et al. (2004) and (2005).

\section{2 - LITERATURE REVIEW}

In spite of the international diffusion of the PE/VC activity [Kenney et al. (2002) count 35 national $\mathrm{PE} / \mathrm{VC}$ associations around the world], the industry is still heavily concentrated in the U.S., where $70 \%$ of worldwide funds raised annually are directed (PWC, 2004). Nonetheless, the PE/VC industry has evolved very differently around the world (Jeng and Wells, 2000) and within countries (Gompers

\footnotetext{
We wish to thank survey participants. Comments from André Aquino, Rodrigo Bueno, Tiago de Melo Cruz, Joubert Castro Filho, Janine Gonçalves, Elizabeth Johnson, Isak Kruglianskas, Roger Leeds, Keith Nelson, Fernando Ruiz, David Stolin, Isaias Sznifer and Vitaly Vorobeychik are gratefully acknowledged. Gisele Gaia and Fábio Barreto provided invaluable assistance. This project was made possible with the full support of FGV Center for PE/VC Research and its sponsors. Ribeiro received grants from the National Council for Scientific and Technological Development (CNPq) and the National Association of Investment Banks (ANBID). Carvalho received grants from the State of São Paulo Research Foundation (FAPESP), CNPq, GVpesquisa and GVcepe. This paper has been prepared for discussion at the 2006 Babson College Entrepreneurship Research Conference (BCERC). It derives from Ribeiro's MSc. thesis: O Modelo Brasileiro de Private Equity e Venture Capital. *Corresponding author. (T) +55 11 3281-3459; leonardo-cepe@fgvsp.br;www.cepe.fgvsp.br.
} 
and Lerner, 1998). Ultimately, the industry's relative size depends on the supply of funds and on the demand for PE/VC. Demand factors are those related to the number and the quality of entrepreneurs seeking capital. Supply factors are those that push investors into the $\mathrm{PE} / \mathrm{VC}$ asset class.

Gompers and Lerner (1998), Jeng and Wells (2000), and Romain and Van Pottelsberghe (2004) have all investigated the determinants of the PE/VC industry's size and found that the most significant factors are: on the demand side - (i) reduction in the capital gains tax (over time); (ii) entrepreneurship activity; (iii) innovative efforts (i.e., overall R\&D expenditure, stock of knowledge and patent fillings, especially when the workforce is mobile and the entrepreneurial activity exceeds a certain level); (iv) GDP growth (in countries with low market rigidity); (v) labor market rigidities (mainly the high-skilled workers, with a stronger effect over early stage investment); and (vi) interest rates (with a positive rather than negative effect). Among the supply factors - (i) allowance for pension funds to investment in the asset class (e.g., ERISA in the U.S.); (ii) growth of the private pension market (explains variability over time but not across countries); (iii) reputation of the established PE/VC organizations; (iv) quality of accounting standards; and (v) long-term against short-term interest rates. Other factors include - (i) volume of IPOs (with stronger effect over later stage investment); (ii) stock market capitalization; and (iii) government programs (with important role in both setting the regulatory framework and galvanizing investment during downturns).

According to Megginson (2004), the differences in the design and the degree of development of the $\mathrm{PE} / \mathrm{VC}$ industry are due to institutional factors, with the country's legal system being paramount. Cumming and MacIntosh (2002) observe that PE/VC managers in high enforcement countries have a greater tendency to invest in high-tech SMEs, exit through IPOs rather than buybacks and obtain higher returns. Cumming et al. (2004) further examined legal system effects on governance structure. Under better legal systems: the faster the origination and screening of deals; the higher the probability of syndication; less frequently funds of the same organization are used to invest in a given company; the easier the board representation of investors; the lower the probability that investors require periodic cash flows prior to exit; and the higher the probability of investment in high-tech companies.

Lerner and Schoar (2005) show that in a bad legal environment, PE/VC managers tend to buy controlling stakes, leaving the entrepreneurial team with weaker incentives. Interestingly, valuations tend be positively correlated with the quality of the legal environment. Kaplan et al. (2003) go deeper into the contractual aspects and found that rights over cash flows, liquidation and control, as well as board participation vary according to the quality of the legal system, the accounting standards and investor protection across countries. However, more sophisticated PE/VC managers tend to operate in the U.S. style irrespective of local institutional concerns. The authors showed that managers operating with convertible preferred stocks are less prone to failure (as measured by survivorship rate). The results suggest that the U.S. contractual style can be efficient in different institutional environments. Bottazzi et al. (2005) corroborate some of the previous results and obtain further evidence on the home-country effect (PE/VC managers operating abroad tend to maintain the investment style used at home). This is observed in managers based in both good and bad legal environments.

While cross-country studies bring light to some important issues, they usually have a caveat of treating each sample country superficially (i.e., only a few available variables are considered, samples are generally incomplete, and so on). To fully observe the richness of a country's PE/VC model, one must understand the local institutional environment thoroughly and gather a dataset rich in terms of variables and coverage. This focused but comprehensive approach has gained attention. For instance, Kummerle (2001) shows that Japan and Germany share similar institutional traits that really set their model of PE/VC apart from the U.S. one. Bruton et al. (2004) show how PE/VC has adapted to the Asian culture, regulations and institutions in general. Dossani and Kenney (2002) discuss policies for the development of PE/VC in India. 
While there is considerable evidence about PE/VC in the U.S., Europe and Asia, there is a general lack of information on its development in Latin America and Brazil, the leading economy in the region. Checa et al. (2001) study the industry in a very early period. Pavani (2003) uses a nonrepresentative sample. Botelho et al. (2003) as well as Ribeiro and Almeida (2005) focus on only one phase of the investment cycle: monitoring and exiting, respectively. Mariz and Savoia (2005) focus on the perspectives for the industry's growth.

\section{3 - THE DATA}

Our study is based on the answers given by all the $71 \mathrm{PE} / \mathrm{VC}$ and Private Investment in Public Equity (PIPE) management organizations with offices in Brazil. They were asked to answer to two extensive pre-tested questionnaires (one firm-specific and another fund-specific) with a total of 160 data entries on the following topics: structure of funds and management organization; investment process (from origination to exit); governance between investors and management organizations, and between management organizations and portfolio companies; and compensation of managers. Our dataset was organized with the purpose of keeping a parallel to Sahlman (1990) who describes the U.S. VC model in terms of those four topics. While this paper we focuses only on the first two, Carvalho et al. (2006) present descriptive statistics on all four topics.

Conducted at the end of 2004 and beginning of 2005, the survey attained a response rate of $100 \%{ }^{1}$. As far as we know, there is no history of such a high rate in PE/VC surveys in Brazil or elsewhere. For the sake of international comparison, the six PIPE organizations were excluded from the sample, leaving us with a 65 organizations. The survey encompasses both domestic and international management organizations. While these organizations were responsible for 94 investment vehicles, information was gathered on only 90 of them.

To identify the population of organizations in Brazil, we relied on the following sources: (i) Endeavor's guide; (ii) the Brazilian Venture Capital Association (ABVCAP) members' list; (iii) list of funds regulated by the local securities and exchanges commission (CVM); (iv) IFC's annual report; (v) Ministry of Science and Technology's (FINEP) internal address book; (vi) list of organizations in Johnson and Pease (2001); and (vii) analysis of news in the media. Only organizations that fit the following description were subsequently considered: invest through equity or quasi-equity (e.g. convertible debt); target non-listed companies; actively monitor portfolio firms and have influence on corporate strategy; invest with exit perspective; and have a team of professional managers.

\section{4 - INSTITUTIONAL ENVIRONMENT AND IDIOSYNCRASIES}

The Brazilian institutional environment is notoriously different from the U.S., especially when it comes to opportunity costs, business informality, entrepreneurial culture, the stock market, corporate governance traditions, legal system efficiency and rights enforcement. The institutional idiosyncrasies constrain the size of the PE/VC pool and tend to generate adaptation failures. Experience in dealing with those problems is subsequently incorporated by PE/VC managers. This dynamic is explained by Leeds and Sunderland (2003) who observed that pioneers obtained mediocre returns in emerging markets. Those PE/VC managers had to review their investment model to continue operating in the region.

\footnotetext{
${ }^{1}$ To certify the relevance of the data collection effort, which took roughly three hours for each firm to complete, ABVCAP, the local stock exchanges (BOVESPA), the Emerging Markets Private Equity Association (EMPEA), FINEP, Endeavor and the IFC were asked to provide us with institutional support that further encouraged participation.
} 
Table 1 depicts the economic and institutional variables that should affect the industry's size and structure. It shows that Brazil boasts a big economy but has severe wealth distribution issues. After 1994, the country tackled the vigorous inflation that used to blur market competition. Since then, high interest rates have prevailed and growth rates have been mediocre when compared to other developing economies (e.g., India and China). This translates into fewer opportunities for business creation and development and a weak competitive position in attracting foreign capital.

The country features high entrepreneurial activity. However, very few entrepreneurs can be classified under the label high-expectation (Reynolds et al., 2003). Due to high labor market rigidity, workers tend to stick to their jobs and entrepreneurs assume great liabilities when employing workers. $\mathrm{PE} / \mathrm{VC}$ investments presume high returns, thus, high-expectation entrepreneurs are the ones more apt to receive them.

Bureaucratic procedures are an endemic problem in Brazil. Opening a business, obtaining construction licenses, paying taxes as well as exporting and importing goods are severely delayed by bureaucratic obstacles. According to Kaufmann et al. (2003) bureaucracy and corruption are strongly correlated. Delays and bribery impose direct and indirect costs for businesses. These costs tend to be higher for smaller enterprises, penalizing early-stage investments.

The tax burden in Brazil is extremely heavy for companies. Tax procedures are complex and the government has difficulty enforcing correct tax payment. Consequently, $40 \%$ of the economy is in the informal sector. Companies with hidden fiscal and labor liabilities present increased risks for PE/VC managers and their investors. Financial reports tend to be less reliable and monitoring becomes more difficult. Thus, PE/VC managers tend to overlook industrial sectors, development stages and companies that operate informally.

The Brazilian legal system is inefficient in the enforcement of creditors' and investors' rights. Thus, capital is expensive and very few companies have access to it. $\mathrm{PE} / \mathrm{VC}$ organizations' access to leverage is very limited, thus buyouts (e.g., MBOs) are highly constrained. In a bad legal environment, the complex contracts used for PE/VC are difficult to enforce. While legislators are working to solve the main regulatory issues, the real problem seems related to the judiciary, which should ultimately enforce laws and contracts. Fortunately, the recognition of arbitration has brought some relief, by allowing some disputes to be settled privately. Several PE/VC vehicles already stipulate arbitration in their bylaws and all funds established under regulation CVM 391, enacted in 2003 , must indicate an arbitration court to solve potential conflicts with portfolio firms.

The existence of infrastructure is an important element for the PE/VC industry. If the right infrastructure is in place, business of all sizes can build on it, creating investment opportunities. Otherwise, building and maintaining infrastructure (e.g., routes, railways, ports, sanitation and energy) should attract important sums that could be provided by $\mathrm{PE} / \mathrm{VC}$ vehicles and covered by government guaranties in public private partnerships (PPP) schemes, similar to the English private finance initiatives (PFI).

Brazil has a relatively small stock market, suggesting the existence of high direct and indirect costs in raising capital from market investors. The stock market has taken and is still taking important steps to increase its quality and accessibility. In the last two years (2004-2005) the market was buoyant. The 2004 offerings represented $1.5 \%$ of GDP, while contemporaneous U.S. IPOs raised $1.0 \%$ of GDP. Healthy stock markets are essential for $\mathrm{PE} / \mathrm{VC}$, allowing investment managers to exit successfully and entrepreneurs to regain control (Gompers and Lerner, 2002). 


\section{5 - THE RELATIVE SIZE OF THE BRAZILIAN PE/VC INDUSTRY}

After 20 years of experience, the Brazilian PE/VC industry has accumulated US $\$ 5.07$ billion in capital under management (i.e., capital already invested plus capital available for new investments), representing $0.84 \%$ of GDP. Table 2 presents the capital evolution between 1999 and 2004. After three years of meager activity, fundraising resumed in 2004 , when it reached $0.08 \%$ of GDP. More than half the amount raised in 2004 was directed to vehicles created specifically for infrastructure investments. Compared to the size of the economy, the fundraising figure is modest. While it can reach more than $1.0 \%$ of the GDP in some developed countries (OECD, 2002), it has never been greater than $0.2 \%$ in Brazil.

Investments are less volatile than capital under management. They reached a maximum of US $\$ 456$ million in $1999(0.08 \%$ of GDP). Since then, it has been stabilized between US\$200 to US\$300 million annually. According to Table 2, investments made by the Brazilian PE/VC industry average $0.06 \%$ of the country's GDP. On the other hand, divestments increased significantly over time, reaching US\$261 million in $2004(0.04 \%$ of GDP). For the first time in the last six years, exit proceedings surpassed investment amounts. This reveals a very positive exit window, as experienced in 2000 .

Compared to other developing economies, Brazil leads Latin American fundraising efforts. Chile raised $0.07 \%$ of GDP. Argentina and Mexico closed 2004 at $0.05 \%$ (VE-LA Data, 2005). Some EastEuropean countries have received more attention (EVCA, 2005), especially Poland (at $0.16 \%$ of GDP) and Hungary (at $0.14 \%$ ). Others have lagged behind Brazil (e.g, the Slovak Republic at $0.02 \%$ and the Czech Republic at $0.01 \%$ ). While fundraising figures were unavailable for Asian countries, 2004 investment values for China, South Korea and India were at $0.10 \%, 0.37 \%$ and $0.13 \%$, respectively, well above Brazil.

\section{6 - AN OVERVIEW OF THE BRAZILIAN PE/VC MODEL}

This section, illustrated by Table 3, offers an overview of the Brazilian PE/VC industry and compares some of the survey results internationally.

\section{1 - Organizational structure}

Most Brazilian PE/VC organizations (64.5\%) are independent and these firms manage $53.6 \%$ of capital. However, the 17 captives of financial institutions still play an important role with $36.8 \%$ of capital. Only four $(6.2 \%)$ corporate ventures have offices in Brazil, with $6.6 \%$ of capital. This distribution puts Brazil on par with Europe, where $66 \%$ of the 750 firms surveyed by Bottazzi et al. (2004, 2005) were independent. However, captives of financial institutions are less common in Europe (at 19\%), while corporate ventures and government-owned organizations are more numerous, at $8 \%$ and $7 \%$, respectively. In Brazil, the government acts as a PE/VC manager by the two branches of its development bank: BNDESPar PE and VC. While the government's role is rather limited, at only $3 \%$ of capital, its portfolio represents $15 \%$ of the number of PE/VC-backed companies. It also acts as an investor in several independently run vehicles.

While PE/VC has its roots in the U.S., most of the Brazilian organizations are domestic (72.2\%) and manage $59.7 \%$ of the capital. The U.S. comes next, with $15.4 \%$ of organizations and $34.7 \%$ of capital. Altogether, those organizations manage $94.4 \%$ of all capital committed to Brazil. This reveals 
the close ties between the U.S. and the Brazilian PE/VC markets, with possible implications for investment style (Kaplan et al., 2003).

Out of 65 organizations, 50, with US $\$ 4.07$ billion in capital (80.3\%), were actively investing by December 2004. The other 15 were inactive and only managed their existing portfolio. However, seven of them, with US\$0.4 billion in capital $(7.9 \%)$, stated the intention to resume investment activity in Brazil. The low abandonment rate reveals a maturing industry and suggests that necessary conditions are already in place to allow adequate $\mathrm{PE} / \mathrm{VC}$ investing and exiting.

In terms of regional distribution, $98.6 \%$ of the capital committed to $\mathrm{PE} / \mathrm{VC}$ is concentrated in organizations located in Sao Paulo and Rio de Janeiro. Moreover, $66.8 \%$ of it is managed by no more than 27 organizations located in the Brazilian financial district (Faria Lima and Berrini avenues), in the city of Sao Paulo. Regional concentration is typical of the PE/VC industry. In the U.S., technology clusters such as Silicon Valley and Route 128 receive $34 \%$ and $15 \%$ of all venture capital investment, respectively (PWC et al., 2005). In India, the industry is mostly concentrated in Mumbai (financial cluster) with 31 organizations. Bangalore, the technology cluster comes second to New Delhi, with eight organizations (Dossani and Kenney, 2002). The clustering of Brazilian PE/VC organizations seems related to the geographic concentration of service providers to assist closing deals, as well as potential partners and acquirers for portfolio companies. As Ribeiro and Almeida (2005) show, Brazilian PE/VC managers tend to spend a lot of time networking with potential acquirers, analyzing their strategies and preparing portfolio companies accordingly.

Similar to the geographic concentration of capital, capital is also concentrated within a few organizations. In Brazil, the ten biggest organizations manage $68.6 \%$ of all capital. On the other hand, the 50 smallest organizations manage $20.1 \%$ of capital. Data from the National Venture Capital Association (2005) suggests that capital concentration is similar in the U.S., but in a different scale. Among the 476 NVCA members, 62 have more than US\$1 billion under management (and up to US\$6.5 billion). The smallest 247 organizations have less than US\$100 million each.

$\mathrm{PE} / \mathrm{VC}$ has several reasons to concentrate regionally and in few organizations. Firstly, it is a relationship intensive business. Managers tend to meet frequently, and work closely with their service providers (lawyers, consultants, auditors) and clients (investors). Secondly, to keep origination, screening and monitoring costs low, they should be as close as possible to their sources of deal. Thirdly, the PE/VC business has important economies of scale (Sahlman, 1990). Managers with good reputation attract more capital and end up with stronger competitive advantages (Gompers and Lerner, 1998).

\section{2 - Human Capital}

The profile of PE/VC managers is a key element, as it impacts the type of company that receives funding and the intensity of monitoring provided by managers (Bottazzi at al., 2004 and Cornelius, 2005). In 2004, the Brazilian PE/VC industry counted 458 professionals consisting of 215 managers and 243 staff personnel (e.g., analysts). Managers are those with decision power over at least one phase of the PE/VC cycle. Sixty percent of managers are partners in their firms, and thus have longterm commitments with the work they do.

Brazilian PE/VC managers are high-skilled professionals: $76.1 \%$ have graduate studies $(3.8 \%$ are $\mathrm{PhDs}, 57.7 \%$ are MBAs or LLMs). Bottazzi et al. $(2004,2005)$ show that two thirds of European $\mathrm{PE} / \mathrm{VC}$ managers have graduate studies. However, the prevalence of Doctors is much higher, at $16 \%$. 
It is very common for a venture capitalist to have an MBA diploma. This is true for one third of managers in Europe, Australia and Honk Kong. In the U.S., almost half are MBAs (Cornelius, 2005).

While $35.6 \%$ of Brazilian PE/VC managers have their most relevant professional experience as financial sector professionals (e.g., investment bankers), more than half (53.5\%) have amassed experience more closely related to the formation and execution of business strategies (e.g., CEOs, entrepreneurs, consultants and angel investors). Only $10.9 \%$ come from the government, academia or law firms. Cornelius (2005) shows that the share of non-financial executives acting as PE/VC managers varies across countries. This profile is prevalent in the U.S., while financial sector executives are predominant in Europe, especially among the new entrants (Bottazzi at al., 2004).

It is important to highlight that the 25 organizations with $49.0 \%$ of capital have at least one manager with ten or more years of $\mathrm{PE} / \mathrm{VC}$ experience, while $92.7 \%$ of capital is managed by organizations that have at least one manager with more than five years of $\mathrm{PE} / \mathrm{VC}$ experience. Generally speaking, the experience of Brazilian PE/VC managers is similar to what Sahlman (1990) found in the U.S. in the early 1990s: $68 \%$ of independent organizations had at least one manager with five or more years of PE/VC experience and one third (with $60 \%$ of capital) had at least one manager with more than ten years of experience.

\section{3 - Portfolio Companies}

In December 2004, 77 out of the 90 investment vehicles had a total of 265 portfolio companies. The other 13 vehicles were still originating their first deal. Due to syndications, the 265 companies represented a total of 315 deals. This means that 233 companies had only one PE/VC investor. The other 45 had at least two, and up to five co-investors. Consequently, less than $30 \%$ of deals in Brazil were syndicated (92/315), while the comparable figure can reach $50 \%$ in Europe (Bottazzi at al., 2004). In fact, two-thirds of European organizations have already taken part in syndications. The comparison suggests that PE/VC organizations in Brazil cooperate little. Possibly, fierce competition for deals and reputation building promotes independent action.

Due to the geographical concentration of organizations in São Paulo and Rio de Janeiro, $65 \%$ of the portfolio is located in the Southeast region, which encompasses the Sates of São Paulo, Rio de Janeiro, Minas Gerais, and Espírito Santo. In fact, almost 90\% of portfolio companies are located in cities served by $\mathrm{PE} / \mathrm{VC}$ offices.

While IT and Electronics (especially software) are preferred sectors, the Brazilian PE/VC portfolio is fairly dispersed across industrial sectors, covering both high technology and traditional industries. In fact, $\mathrm{PE} / \mathrm{VC}$ is particularly adapted to financing high-growth and innovative firms such as hightech businesses. In 19 out of 29 countries compared by the OECD (2005), at least $40 \%$ of investments go to IT, telecom, biotechnology and healthcare. In Ireland, Canada and the U.S., these sectors receive more than $70 \%$ of investments. On the opposite side of the spectrum, Spain, the Slovak Republic, Portugal and Netherlands have less than $25 \%$ of investments made in those sectors.

While we have no data on the amount invested in each sector, comparison with Europe in terms of the number of portfolio companies shows that $30 \%$ of European PE/VC-backed companies are in the software and Internet sectors (Bottazzi et al., 2004). In Brazil, 22.1\% are in these sectors. Industrial products represent $11 \%$ of the European portfolio and $8.7 \%$ in Brazil. The main difference is in the attention given to biotech and pharmaceuticals. These sectors constitute $14 \%$ of the European portfolio, but only $4.9 \%$ of the Brazilian PE/VC-backed firms. According to Sahlman (1990), PE/VC organizations tend to specialize according to industrial sectors. However, the three sectors that receive 
most deals in Brazil represent only $45 \%$ of the portfolio. This number reaches $55 \%$ in Europe, suggesting that $\mathrm{PE} / \mathrm{VC}$ managers in Brazil take a rather general approach towards industry sector specialization.

To Sahlman (1990), PE/VC was designed to finance companies in the early stages of development, when little or no track record has been built; few tangible assets are in place; and negative cash flows prevail. Depending on their growth potential, firms in more mature stages can also be considered for $\mathrm{PE} / \mathrm{VC}$ investments. In Brazil, $41.1 \%$ of portfolio companies received their first PE/VC injections in the form of seed capital (13.7\%) or start-up capital (27.4\%), considered as early-stage investments. However, the majority of the portfolio (37.3\%) was in expansion deals. Later-stage was represented by $16 \%$ of portfolio companies. Other stages, such as acquisition finance, manager buyout/in, bridge financing and turnaround accounted for only 5.7\%. According to Bottazzi et al. (2004), the European $\mathrm{PE} / \mathrm{VC}$ industry is more reliant on early-stage deals, as $42 \%$ of PE/VC-backed companies were startups and $17 \%$ received seed capital. In the U.S., PE/VC is also inclined to finance early-stage companies. In a recent survey, NVCA (2005) discovered that their members were expecting $51.5 \%$ of deals to be made in the early-stage segment.

\section{4 - Investors}

In Brazil, $17.2 \%$ of the capital committed comes from pension funds. Among them, domestic pension funds play a leading role, with $78 \%$ of the capital. Corporations bring in another $15.9 \%$ (43\% of it of foreign origin). Banks, especially international investment banks, contribute $10.3 \%$. The rest is held by Fund of funds, trusts, endowments, wealthy individuals, other PE/VC funds, insurance firms, partners, multilateral institutions etc. The government has committed US\$255 million (6.4\%) in 30 PE/VC vehicles through its several arms (e.g., FINEP, BNDES, SEBRAE and Banco do Nordeste). Such a development role is also played by multilateral institutions, which brought US\$131 million (3.3\%) to 20 vehicles operating in Brazil. According to Megginson (2004), pension funds are also the main investor in the U.S. PE/VC industry, while the European PE/VC industry relies more on banks, insurance firms and government agencies.

According to Sahlman (1990), managing-partners usually invest $1.0 \%$ of the funds in order to align interests with investors. In Brazil, they are responsible for 5\% of the capital. However, this share can reach $14.5 \%$ in the 27 vehicles in which outside investors and managing-partners co-invest. The difference between the U.S. and Brazil suggests that in a maturing PE/VC industry, in which managers have not yet amassed a solid track record, and where enforcement of rights is weaker, managers will have to contribute more personal resources in order to attract investors.

\section{5 - Exits}

In 2004 and 2005, 16 Brazilian companies went through Initial Public Offerings (IPOs) at the local stock exchange (BOVESPA), raising approximately US $\$ 3.6$ billion. While this represented the resurgence of IPOs in Brazil, it also called attention to a different fact: nine out of the 16 issuing companies were financed by PE/VC, namely: Natura (cosmetics), Gol (low cost/low fare airliner), ALL (railways and logistics), DASA (laboratorial services), CPFL (power generation and distribution), TAM (airliner), Submarino.com (internet reseller), Localiza (car rental) and UOL (Internet service provider). More than $50 \%$ of the funds raised at the stock exchanges were directed to these private equity-backed companies. This suggests that the Brazilian PE/VC industry has achieved enough experience and size to make a strong impact on the stock market. 
Despite significant IPO activity in 2004 and 2005, most exits performed in Brazil are realized through trade-sales and buybacks. In 2000, while the market was experiencing a period of high liquidity, not a single exit was performed in the stock markets, but 13 trade-sales occurred and the amount divested reached its maximum. In the U.S., IPOs tend to occur more often than trade-sales, while European $\mathrm{PE} / \mathrm{VC}$ firms usually have $30 \%$ of exits performed through trade-sales and only $5 \%$ in the stock market.

\section{7 - CONCLUDING REMARKS}

This paper offers a first description of the Brazilian PE/VC market in terms of size and structure. Results are compared internationally and suggest that the Brazilian PE/VC industry is relatively small compared to the size of the Brazilian economy. Annual investments are around $0.06 \%$ of GDP against $1.0 \%$ for some developed countries. Nevertheless, the industry has proven economically relevant, bringing several companies to the stock markets.

The PE/VC industry is heavily limited by Brazilian institutional idiosyncrasies. At the same time, the lack of infrastructure (e.g., transportation, energy and telecommunications) and security still provide opportunities for PE/VC type of investments. As a main finding, this study identifies differences and similarities between the American and the Brazilian PE/VC models. Similarities were expected since PE/VC was imported from the U.S. and most managers have close ties with their American peers: (i) $\mathrm{PE} / \mathrm{VC}$ firms are mainly independent and manage capital from institutional investors; (ii) capital is heavily concentrated regionally as well as in few organizations; (iii) investments are made within a close range from organizations; (iv) software and IT are preferred sectors; and (v) managers are highly qualified. The main differences suggest that the model has adapted to the new environment: (i) in line with a lack of high-expectation entrepreneurship, there is a tendency to invest in more advanced stages; (ii) since credit is scarce, few LBOs take place; (iii) low levels of sector specialization suggest few opportunities within each sector; (iv) organizations concentration in the financial cluster suggests a quest for commercial partners and strategic buyers to portfolio companies (IPO is a quite rare exit mechanism); and (v) Brazilian PE/VC regulation recognizes the inefficiency of the legal system and obliges the use of arbitration.

The survey shows that $90 \%$ of organizations operating in Brazil have encountered the necessary conditions to operate and intend to continue or resume investing in the country. Brazil's economic and institutional environment is becoming more supportive for $\mathrm{PE} / \mathrm{VC}$. In the last five years many important steps were taken: (i) the resurgence of IPOs in general and PE/VC-backed offerings in particular showed that the stock market is a useful exit mechanism. As the literature shows, IPOs encourage more fundraising; (ii) pension funds are now allowed to invest up to $20 \%$ of their assets in $\mathrm{PE} / \mathrm{VC}$. They have quickly become the major PE/VC investors in Brazil. As private pension schemes and $\mathrm{PE} / \mathrm{VC}$ become more popular, their share of committed capital should increase; (iii) interest rates are declining and are expected to further decline against short-term rates, making PE/VC more attractive to investors and reducing the cost of credit, thus encouraging leveraged buyouts; (iv) the newest $\mathrm{PE} / \mathrm{VC}$ regulation is sound and protective of institutional investors and individuals; (iv) the Brazilian legal system has recognized arbitration; (v) the stock market has established mechanisms to differentiate good corporate governance practices and promote SME listings; (vi) the public private partnership law (PPP) was enacted in 2004. The lack of infrastructure, transportation services and security continues to represent long-term investment opportunities and have higher chances to be divested through IPOs (e.g., ALL, CPFL, Gol and TAM); (vii) the new bankruptcy law will tend to decrease procedural time, thus facilitating turnarounds; (viii) tax authorities are now considering $\mathrm{PE} / \mathrm{VC}$ vehicles as closed-end funds for tax purposes; (ix) capital gains tax was reduced from $22 \%$ to $15 \%$, with full exemption to foreign investors; $(\mathrm{x})$ the Innovation law should promote highexpectation entrepreneurship; (xi) the new corporate law increased investor protection. 
While the government is taking important steps, it has much work to do in order to set the right framework for SME creation and development in the country (e.g. simplification of tax procedures, reduction of the tax burden on formal companies and enforcement of rights).

We believe that this study yields three contributions. First, it sheds some light on how the institutional environment affects financial intermediation. Second, it brings concrete evidence about the adaptability of PE/VC to other countries in general and to emerging markets in particular. Third, it raises issues that are relevant to policy makers in Brazil and other emerging countries trying to foster entrepreneurship, economic growth and competitiveness. The caveats are related to the lack of contemporaneous data to compare all variables adequately. Moreover, all comparisons are static and ignore the evolution of the $\mathrm{PE} / \mathrm{VC}$ industry over time. For the sake of simplification, the PE/VC industry was treated as homogenous, irrespective of years of experience, origin (domestic or foreign), investment focus and country of domicile of organizations.

\section{8 - REFERENCES}

Botelho, A., G. Harckbart, \& J. Lange. (2003) "Do Brazilian Venture Capitalists Add Value to Their Portfolio Companies?" Frontiers of Entrepreneurship Research. Wellesley, MA: Babson College.

Bottazzi, L., M. Da Rin, \& T. Hellman. (2005) "What Role of Legal Systems in Financial Intermediation? Theory and Evidence." European Corporate Governance Institute.

Bottazzi, L., M. Da Rin, \& T. Hellman. (2004) "The Changing Face of the European Venture Capital Industry: Facts and Analysis." Journal of Private Equity 8(1).

Bruton, G., D. Ahlstrom, \& K. Yeh. (2004) "Understanding Venture Capital in East Asia: The Impact of Institutions on the Industry Today and Tomorrow." Journal of World Business 39(1): 72-88.

Carvalho, G., L. Ribeiro, \& C. Furtado. (2006) Private Equity and Venture Capital in Brazil - The first Census. Rio de Janeiro, RJ: Fundação Getúlio Vargas - Editora.

Checa, G., E. Leme, \& C. Schreier. (2001) "The Venture Capital and Private Equity Industry in Brazil." Journal of Private Equity 4(4): 46-67.

Cornelius, B. (2005) "The Institutionalisation of Venture Capital." Technovation 25: 599-608.

Cumming, D., \& J. MacIntosh. (2002) "A Law and Finance Analysis of Venture Capital Exits in Emerging Markets." Alberta: University of Alberta.

Cumming, D., D. Schmidt, \& U. Walz. (2004). "Legality and Venture Governance Around the World."

Dossani, R., \& M. Kenney. (2002) "Creating an Environment for Venture Capital in India." World Development 30(2): 227-253.

EVCA. (2005) "Final Activity Figures for 2004." Brussels.

Gompers, P., \& J. Lerner. (2002) The Venture Capital Cycle. Cambridge: The MIT Press.

Gompers, P., \& J. Lerner. (1998) "What Drives Venture Fundraising?" Brookings Papers on Economic Activity: Microeconomics 149-204.

Jeng, L, \& P. Wells. (2000) "The Determinants of Venture Capital Funding: Evidence Across Countries." Journal of Corporate Finance 6(3): 241-289. 
Johnson, H., \& R. Pease. (2001) Latin American Private Equity Review \& Outlook. Wellesley: Asset Alternatives.

Kaplan, S., F. Martel, \& P. Strömberg. (2003) "How do Legal Differences and Learning Affect Financial Contracts?" National Bureau of Economic Research.

Kaufmann, D., A. Kraay, \& M. Mastruzzi. (2003) Governance Matters III: Governance Indicators for 1996-2002. Washington: World Bank Policy Research Report Series.

Kenney, M, K. Han, \& S. Tanaka. (2002) "The Globalization of Venture Capital: The Cases of Taiwan and Japan."

Kuemmerle, W. (2001) "Comparing Catalysts of Change: Evolution and Institutional Differences in the Venture Capital Industry in the U.S., Japan and Germany." In Research on Technological Innovation, Management and Policy, ed. R. Burgelman \& H. Chesbrough, 227-261. Greenwich, CT: JAI Press.

Leeds, R., \& J. Sunderland. (2003) "Private Equity Investing in Emerging Markets." Journal of Applied Corporate Finance 15(4): 8-16.

Lerner, J., \& A. Schoar. (2005) "Does Legal Enforcement Affect Financial Transactions? The Contractual Channel in Private Equity." Quarterly Journal of Economics 120(1).

Mariz, F., \& J. Savoia. (2005) "Private Equity in Brazil: A Comparative Perspective." Journal of Private Equity.

Megginson, W. (2004) "Toward a Global Model of Venture Capital?" Journal of Applied Corporate Finance 16(1): 8-26.

OECD. (2002) Venture Capital: Trends and Policy Recommendations. Paris: OECD.

OECD. (2005) Developments in Venture Capital and Private Equity Since the end of "Tech Bubble." Paris: OECD.

Pavani, C. (2003) O Capital de Risco no Brasil: Conceito, Evolução e Perspectivas. Rio de Janeiro, RJ: E-papers.

PriceWaterhouseCoopers, Venture Economics, \& NVCA. (2005) Moneytree Survey: Full Year and Q4 2004 Results - US Report.

PriceWaterhouseCoopers. (2004) Global Private Equity 2004.

Reynolds, P., M. Hay, W. Bygrave, S. Camp, \& E. Autio. (2003) Global Entrepreneurship Monitor: 2003 Executive Report. London: Babson College \& London Business School.

Ribeiro, L., \& M. Almeida. (2005) "Estratégia de Saída em Capital de Risco." Revista de Administração da Universidade de São Paulo (RAUSP) 40(1): 55-67.

Romain, A., \& B. Van Pottelsberghe. (2004) "The Determinants of Venture Capital: Additional Evidence." Deutsche Bundesbank, Studies of the Economic Research Centre 19.

Sahlman, W. (1990) "The Structure and Governance of Venture-Capital Organizations." Journal of Financial Economics 27(2): 473-521. 


\section{Table 1 - Economic and Institutional Indicators}

Data sources are: World Bank Development Indicators, 2005; World Bank Doing Business Survey, 2005;

IMD Global Competitiveness Yearbook, 2005; Global Entrepreneurship Monitor, 2004; Lambsdorff, J.

"Corruption Perception Index." Transparency International, 2005. Average, minimum and maximum figures

are based on a sample of 37 economies with PE/VC industries: South Africa, Germany, Argentina,

Australia, Austria, Belgium, Brazil, Canada, Chili, China, Singapore, Korea, Denmark, Slovak Republic,

Spain, U.S., Finland, France, Greece, Netherlands, Hong Kong, Hungry, India, Indonesia, Ireland, Israel,

Italy, Japan, Mexico, Norway, New Zealand, Poland, Portugal, U.K., Czech Republic, Sweden and

Switzerland.

\begin{tabular}{|c|c|c|c|c|c|c|}
\hline Indicator & Description & Year & Brazil & Min. & Avg. & Max. \\
\hline Income and consumption & Richest 20\% (\%) & 2001 & 63.2 & 34.8 & 43.6 & 63.2 \\
\hline GDP per capita & USD & 2005 & 7,969 & 3,013 & 22,635 & 39,397 \\
\hline Total Entrepreneurship Activity & Index $(\%)$ & 2004 & 13.5 & 3.7 & 6.8 & 14.7 \\
\hline Growth & $\%$ of GDP & $\begin{array}{l}1980 \\
1990\end{array}$ & 2.7 & -0.7 & 3.3 & 10.3 \\
\hline Growth & $\%$ of GDP & $\begin{array}{l}1990 \\
2003\end{array}$ & 2.6 & 1.2 & 3.3 & 9.6 \\
\hline Inflation & $(\%)$ & 2004 & 5.7 & 0.1 & 2.7 & 8.5 \\
\hline Firm Growth & Increase in Sales $(\%)$ & $\begin{array}{l}1996 \\
1999\end{array}$ & 3.0 & -5.0 & 15.9 & 33.0 \\
\hline Real interest rate & $(\%)$ & 2003 & 48.2 & -1.5 & 5.8 & 48.2 \\
\hline Creditor protection & Index ( 0 to 10$)$ & 2005 & 2.0 & 2.0 & 5.9 & 10 \\
\hline Investor protection & Index $(0$ to 10$)$ & 2005 & 5.3 & 3.3 & 6.0 & 9.7 \\
\hline Enforcement of contracts & Time (days) & 2005 & 546 & 48 & 300.9 & 1,390 \\
\hline Enforcement of contracts & Cost $(\%$ of debt $)$ & 2005 & 15.5 & 4.2 & 12.8 & 43.1 \\
\hline Legal environment & Index $(0$ to 10$)$ & 2005 & 2.8 & 2.0 & 4.7 & 7.9 \\
\hline Cost of capital hampers business & Index $(0$ to 10$)$ & 2005 & 1.8 & 1.8 & 5.9 & 8.1 \\
\hline Starting a business & Cost (\% income/capita) & 2005 & 10.1 & 0.0 & 9.9 & 61.7 \\
\hline Starting a business & Time (days) & 2005 & 152 & 2 & 29.3 & 152 \\
\hline Trading Across Borders & Time for export (days) & 2005 & 39 & 5 & 16 & 39 \\
\hline Trading Across Borders & Time for import (days) & 2005 & 43 & 5 & 18.3 & 43 \\
\hline Closing a business & Time (years) & 2005 & 10 & 0.4 & 2.5 & 10 \\
\hline Closing a business: Recovery rate & (cents/dollar) & 2005 & 0.5 & 0.5 & 60.8 & 92.7 \\
\hline Bureaucracy & Index $(0$ to 10$)$ & 2005 & 1.5 & 1.1 & 3.3 & 6.7 \\
\hline Corruption & Index $(0$ to 10$)$ & 2005 & 3.7 & 2.2 & 6.6 & 9.6 \\
\hline Paying taxes & Time (hours) & 2005 & 2,600 & 30 & 334.9 & 2,600 \\
\hline Total tax payable & (\% of gross profit) & 2005 & 148 & 14 & 48.1 & 148 \\
\hline Tax hampers entrepreneurship & Index $(0$ to 10$)$ & 2005 & 2.0 & 2 & 5.0 & 8 \\
\hline Fiscal evasion hampers firms & Index ( $\%$ of responses) & 2005 & 39 & 13 & 31.0 & 49 \\
\hline Informality & $\%$ of GDP & 2005 & 39.8 & 8.8 & 19.6 & 39.8 \\
\hline Internet users & $\%$ of population & 2003 & 0.82 & 0.17 & 33.83 & 61.0 \\
\hline Internet cost & $\begin{array}{l}\text { Cost for } 20 \text { hours } \\
\text { (USD) }\end{array}$ & 2004 & 28 & 4 & 19.9 & 38 \\
\hline Internet cost & $\%$ of GDP per capita & 2005 & 11.8 & 0.2 & 4.4 & 37.6 \\
\hline Routes & $\mathrm{Km}$ (million) & 2005 & 1.7 & 0.002 & 0.6 & 6.4 \\
\hline Paved routes & $(\%)$ & 2005 & 5.5 & 5.5 & 72.8 & 100 \\
\hline Railroads & Km (thousand) & 2005 & 30.4 & 0.3 & 18.3 & 141.9 \\
\hline Crimes hamper firm activity & $\%$ of answers & 2005 & 52.2 & 4.9 & 21.2 & 52.2 \\
\hline Labor market rigidity & Index $(0$ to 100$)$ & 2005 & 56 & 0 & 35.9 & 66 \\
\hline Firing Workers & Costs (weeks of wage) & 2005 & 165 & 0 & 44.1 & 165 \\
\hline Market capitalization & $\%$ of GDP & 2005 & 46.4 & 8.5 & 78.8 & 456.1 \\
\hline Capital markets accessibility & Index $(0$ to 10$)$ & 2005 & 5.8 & 3.4 & 7.4 & 9.6 \\
\hline R\&D expenditure & $\%$ of GDP & 2005 & 1.0 & 0.8 & 1.7 & 2.5 \\
\hline Enrollment in higher education & $\%$ of population & $\begin{array}{l}2002 \\
2003\end{array}$ & 18 & 11 & 50.7 & 86 \\
\hline
\end{tabular}


Table 2 - Capital Flows in the Brazilian PE/VC Industry and Exit Activity

Aggregated values of capital under management, funds raised, investment and exits for the 65 organizations. Funds raised were calculated based on the increase of capital in each organization from one year to the next. Since the series starts in 1999, this year's figure is unavailable. Figures in brackets are percentages of annual GDP. GDP figures obtained with the Brazilian Central Bank. Investment figures are underestimated since eight of the responding organizations did not provide this information. Capital under management is more precise, as only two small-size organizations did not provide this information. Exits are measured in number of transactions made annually, by mechanism. Full exit means sale of all the stock owned by the PE/VC vehicle in a specific firm, or a complete liquidation of its assets. Where exit took place by means of several partial exits, the last transaction is regarded as a full exit and all prior ones are classified as partial exits, except for IPOs, since the listing represents a liquidity event. IPO: initial public offering. Trade-sale: sale of all the stock to a strategic buyer, generally an industrial group interested in the vertical or horizontal integration of the target firm. Secondary sale: means the sale of shares to a temporary investor. Buyback: means the stock repurchase by the business owner or entrepreneur. Write-off/down means full liquidation of the firm's asset and implies termination of operations. Partial exits: includes secondary-sales, buybacks and amortization of convertible debt. Average divestment is the value of divestments to number of full and partial exits (except write-offs/down). Figures in parentheses stand for percentages of the total.

\begin{tabular}{cccccccc}
\hline \hline Capital & $\mathbf{1 9 9 9}$ & $\mathbf{2 0 0 0}$ & $\mathbf{2 0 0 1}$ & $\mathbf{2 0 0 2}$ & $\mathbf{2 0 0 3}$ & $\mathbf{2 0 0 4}$ & Avg. \\
(US\$ million) & 3,583 & 4,778 & 4,846 & 4,553 & 4,577 & 5,071 & $\mathbf{4 , 5 6 8}$ \\
Under Management & {$[0.67]$} & {$[0.79]$} & {$[0.95]$} & {$[0.99]$} & {$[0.90]$} & {$[0.84]$} & {$[\mathbf{0 . 8 6}]$} \\
Raised & - & 1.212 & 290 & 260 & 159 & 473 & $\mathbf{4 7 9}$ \\
& - & {$[0.20]$} & {$[0.06]$} & {$[0.06]$} & {$[0.03]$} & {$[0.08]$} & {$[\mathbf{0 . 0 9}]$} \\
Invested & 456 & 379 & 281 & 261 & 256 & 253 & $\mathbf{3 1 4}$ \\
& {$[0.08]$} & {$[0.06]$} & {$[0.05]$} & {$[0.06]$} & {$[0.05]$} & {$[0.04]$} & {$[\mathbf{0 . 0 6}]$} \\
Divested & 203 & 282 & 65 & 41 & 52 & 261 & $\mathbf{1 5 1}$ \\
& {$[0.04]$} & {$[0.05]$} & {$[0.01]$} & {$[0.01]$} & {$[0.01]$} & {$[0.04]$} & {$[\mathbf{0 . 0 3}]$} \\
\hline Exit Mechanisms & $\mathbf{1 9 9 9}$ & $\mathbf{2 0 0 0}$ & $\mathbf{2 0 0 1}$ & $\mathbf{2 0 0 2}$ & $\mathbf{2 0 0 3}$ & $\mathbf{2 0 0 4}$ & Total \\
(Number of deals) & - & - & - & - & - & 9 & $\mathbf{9}$ \\
- IPO & - & - & - & - & - & $(29.0)$ & $\mathbf{( 5 . 6 )}$ \\
- Trade-sale & 4 & 13 & 8 & 6 & 6 & 15 & $\mathbf{5 2}$ \\
- Secondary-sale & $(57.1)$ & $(39.4)$ & $(21.6)$ & $(24.0)$ & $(27.3)$ & $(48.4)$ & $\mathbf{( 3 2 . 1 )}$ \\
- Buyback & - & 16 & 1 & 1 & 4 & 2 & $\mathbf{2 4}$ \\
& - & $(48.5)$ & $(27.0)$ & $(4.0)$ & $(18.2)$ & $(6.5)$ & $\mathbf{( 1 4 . 8 )}$ \\
- Write-off/down & 3 & 1 & 8 & 3 & 9 & 8 & $\mathbf{3 2}$ \\
& $(42.9)$ & $(3.0)$ & $(21.6)$ & $(12.0)$ & $(40.9)$ & $(25.8)$ & $\mathbf{( 1 9 . 6 )}$ \\
Total: Full Exits & - & 3 & 20 & 15 & 3 & 4 & $\mathbf{4 5}$ \\
Total: Partial Exits & $\mathbf{7}$ & $(9.1)$ & $(54.1)$ & $(60.0)$ & $(13.6)$ & $(12.9)$ & $\mathbf{( 2 7 . 8 )}$ \\
\hline \hline
\end{tabular}


Table 3 - Survey Selected Variables

In Organization Structure, numbers represent percentage of organizations and capital under management (in parentheses), except for Capital Concentration, where the numbers in brackets mean the average fund size. Activity refers to the actual/intended investment activity. In Human Capital, figures represent the number of professionals or managers and percentage of the total (in parentheses). Job Title presents statistics on all professionals while other variables refer to managers only. In Experience, the job as CEO of a financial institution was categorized as financial. Years of Experience refer to the number of organizations with at least one manager with the accumulated experience, and the percentage of capital under management at these organizations (in parentheses). In Portfolio Companies, numbers presented in Investment Type refer to deals. All other variables consider only invested companies individually. In Geographic Distribution, Industry and Stage, the two portfolio companies for which we have no data were considered as Other. In Investors, the numbers refer to the percentage of capital under management and the percentage of foreign capital (in braces). Unidentified sources of capital were included in Other.

\begin{tabular}{|c|c|c|c|c|}
\hline \multicolumn{5}{|c|}{ Organizational Structure } \\
\hline Affiliation & $\begin{array}{c}\text { Independent } \\
64.5(53.6) \\
\end{array}$ & $\begin{array}{c}\text { Financial Institution } \\
26.2(36.8) \\
\end{array}$ & $\begin{array}{c}\text { Corporate } \\
6.2(6.6) \\
\end{array}$ & $\begin{array}{c}\text { Government } \\
3.1(3.0) \\
\end{array}$ \\
\hline Origin & $\begin{array}{c}\text { Brazil } \\
72.2(59.7)\end{array}$ & $\begin{array}{c}\text { U.S. } \\
15.4(34.7) \\
\end{array}$ & $\begin{array}{l}\text { Europe } \\
6.2(1.8) \\
\end{array}$ & $\begin{array}{c}\text { Other } \\
6.2(3.8) \\
\end{array}$ \\
\hline $\begin{array}{l}\text { Investment } \\
\text { Activity }\end{array}$ & $\begin{array}{c}\text { Inactive/Inactive } \\
10.8 \text { (n.a.) } \\
\end{array}$ & $\begin{array}{c}\text { Inactive/Active } \\
10.8(7.9) \\
\end{array}$ & $\begin{array}{c}\text { Active/Active } \\
76.9(80,3) \\
\end{array}$ & $\begin{array}{c}\text { Inactive/Undecided } \\
1.5 \text { (n.a.) } \\
\end{array}$ \\
\hline $\begin{array}{l}\text { Geographic } \\
\text { Concentration }\end{array}$ & $\begin{array}{c}\text { São Paulo (Total) } \\
67.9(79.9)\end{array}$ & $\begin{array}{c}\text { São Paulo (Faria } \\
\text { Lima/Berrini) } \\
40.9(66.8)\end{array}$ & $\begin{array}{c}\text { Rio de Janeiro } \\
24.6(18.7)\end{array}$ & $\begin{array}{c}\text { Other } \\
7.5(1.4)\end{array}$ \\
\hline $\begin{array}{l}\text { Capital } \\
\text { Concentration }\end{array}$ & $\begin{array}{c}5 \text { biggest } \\
(50.5)[513] \\
\end{array}$ & $\begin{array}{c}10 \text { biggest } \\
(68.6)[348] \\
\end{array}$ & $\begin{array}{l}15 \text { biggest } \\
(79.9)[270] \\
\end{array}$ & $\begin{array}{l}\text { 50 smallest } \\
(20.1)[23] \\
\end{array}$ \\
\hline \multicolumn{5}{|c|}{ Human Capital } \\
\hline Job Title & $\begin{array}{c}\text { Managing-Partner } \\
128(27.9)\end{array}$ & $\begin{array}{c}\text { Manager } \\
87(19.0) \\
\end{array}$ & $\begin{array}{c}\text { Analyst } \\
135(18.1)\end{array}$ & $\begin{array}{c}\text { Other } \\
108(35.0)\end{array}$ \\
\hline Education & $\begin{array}{l}\text { Ph.D. } \\
8(3.8) \\
\end{array}$ & $\begin{array}{c}\text { MBA/LLM } \\
123(57.7) \\
\end{array}$ & $\begin{array}{c}\text { Specialization } \\
31(14.6) \\
\end{array}$ & $\begin{array}{c}\text { College or less } \\
51(23.9) \\
\end{array}$ \\
\hline Experience & $\begin{array}{l}\text { Financial } \\
75(35.6) \\
\end{array}$ & $\begin{array}{c}\text { CEO/Entrep./Angel } \\
74(35.0) \\
\end{array}$ & $\begin{array}{c}\text { Consulting } \\
39(18.5) \\
\end{array}$ & $\begin{array}{c}\text { Other } \\
23(10.9) \\
\end{array}$ \\
\hline $\begin{array}{l}\text { Years of } \\
\text { Experience }\end{array}$ & $\begin{array}{c}\mathbf{x} \geq \mathbf{2 0} \\
12.3(21.3)\end{array}$ & $\begin{array}{c}\mathbf{x} \geq \mathbf{1 5} \\
29.2(37.4)\end{array}$ & $\begin{array}{c}\mathbf{x} \geq \mathbf{1 0} \\
38.5(49.0)\end{array}$ & $\begin{aligned} \mathbf{x} & \geq \mathbf{5} \\
75.4 & (92.7)\end{aligned}$ \\
\hline \multicolumn{5}{|c|}{ Portfolio Companies } \\
\hline $\begin{array}{l}\text { Investment } \\
\text { Type }\end{array}$ & $\begin{array}{c}\text { Independent } \\
223(70.8)\end{array}$ & $\begin{array}{c}\text { Syndicated (lead) } \\
42(13.3)\end{array}$ & $\begin{array}{c}\text { Syndicated nonlead } \\
50(15.9)\end{array}$ & - \\
\hline $\begin{array}{l}\text { Geographic } \\
\text { Distribution }\end{array}$ & $\begin{array}{c}\text { Southeast (Total) } \\
171(65.0)\end{array}$ & $\begin{array}{c}\text { Southeast (São } \\
\text { Paulo) } \\
100(38.0)\end{array}$ & $\begin{array}{l}\text { South } \\
67(25.5)\end{array}$ & $\begin{array}{c}\text { Other } \\
27(9.5)\end{array}$ \\
\hline Industry & $\begin{array}{c}\text { Software/Internet } \\
68(22.1)\end{array}$ & $\begin{array}{c}\text { Industrial Products } \\
23(8.7)\end{array}$ & $\begin{array}{c}\text { Biotech/Pharma } \\
13(4.9)\end{array}$ & $\begin{array}{c}\text { Other } \\
161(60.8)\end{array}$ \\
\hline Stage & $\begin{array}{c}\text { Seed \& Start-Up } \\
108(41.1)\end{array}$ & $\begin{array}{c}\text { Expansion } \\
98(37.3)\end{array}$ & $\begin{array}{c}\text { Later Stage } \\
42(16.0)\end{array}$ & $\begin{array}{c}\text { Other } \\
17(5.7)\end{array}$ \\
\hline & & Investors & & \\
\hline $\begin{array}{l}\text { Investor } \\
\text { Category }\end{array}$ & $\begin{array}{c}\text { Pension Funds } \\
17.2\{24.0\}\end{array}$ & $\begin{array}{c}\text { Corporations } \\
15.9\{43.0\} \\
\end{array}$ & $\begin{array}{c}\text { Banks } \\
10.3\{78.0\}\end{array}$ & $\begin{array}{c}\text { Other } \\
56.6\{83.5\}\end{array}$ \\
\hline
\end{tabular}

